\title{
The UK market for energy service contracts in 2014-2015
}

\author{
Colin Nolden • Steve Sorrell
}

Received: 8 September 2015 / Accepted: 1 February 2016/Published online: 16 February 2016

(C) The Author(s) 2016. This article is published with open access at Springerlink.com

\begin{abstract}
This paper provides an overview of the UK market for energy service contracts in 2014 and highlights the growing role of intermediaries. Using information from secondary literature and interviews, it identifies the businesses offering energy service contracts, the sectors and organisations that are purchasing those contracts, the types of contract that are available, the areas of market growth and the reasons for that growth. The paper finds that the UK market is relatively large, highly diverse, concentrated in particular sectors and types of site and overwhelmingly focused upon established technologies with high rates of return. A major driver is the emergence of procurement frameworks for energy service contracts in the public sector. These act as intermediaries between clients and contractors, thereby lowering transaction costs and facilitating learning. The market is struggling to become established in commercial offices, largely as a result of split incentives, and is unlikely to develop further in this sector without different business models, tenancy arrangements and policy initiatives. Overall, the paper concludes that energy service contracts can play an important role in the transition to a low-carbon economy, especially when supported by intermediaries, but their potential is still limited by high transaction costs.
\end{abstract}

C. Nolden $\cdot$ S. Sorrell $(\bowtie)$

Centre on Innovation and Energy Demand, Science Policy

Research Unit (SPRU), University of Sussex, Falmer,

Brighton BN1 9SL, UK

e-mail: s.r.sorrell@sussex.ac.uk
Keywords ESCOs $\cdot$ Energy performance contracts . Intermediaries $\cdot$ Procurement frameworks

\section{Introduction}

Many commentators argue that the transition to a sustainable, low-carbon economy will require companies to evolve from selling increasing volumes of products (e.g. cars, lights, motors) to efficiently delivering final services to consumers (e.g. mobility, illumination, motive power) at lower economic, energy and environmental costs (Lay et al. 2009; Stahel 1997; Steinberger et al. 2009). For example, rather than simply selling lighting equipment, companies (or 'contractors') may provide agreed levels of illumination for a client and take responsibility for the ownership, installation, operation, maintenance, upgrading, replacement and/or disposal of the necessary equipment under the terms and conditions of a long-term contract. Such energy service contracts may capitalise on the core strengths of the contractor (or energy service company-ESCO), achieve cost savings for the client, mobilise low-cost finance and reduce the energy and emissions required to obtain a given level and quality of illumination. In contrast to traditional product sales, this type of contract may incentivise the contractor to minimise the life-cycle costs of the relevant equipment, to select the appropriate size and quality of equipment, to improve energy efficiency and/or to extend product life. As such, a shift from product sales to energy service contracts may provide an effective means of reducing both end use and embodied energy demand. 
Although these expectations are informed by real-world experience, the UK market for energy service contracts has not taken off to the extent that some commentators had hoped (Hansen et al. 2009; Stahel 2006) - suggesting either that the expectations were overoptimistic, or that important barriers have yet to be overcome. To explore these issues further, this paper provides an overview of the UK market for energy service contracts in 2014 and highlights the growing role of intermediaries. It summarises the businesses and partnerships offering energy service contracts in the UK in 2014, the sectors and organisations that are purchasing those contracts, the types of contract that are available, the areas of market growth and some of the reasons for that growth. Put simply, the paper summarises who is providing what to whom, on what terms and why.

The paper is based upon information compiled during 2014-2015 from primary and secondary literature, a survey of energy service companies (ESCOs), attendance at conferences and workshops and semi-structured interviews with 23 sector representatives. Documentary sources were identified from journal databases and web searches and included a large proportion of 'grey literature'. Interviewees included monitoring and verification $(\mathrm{M} \& \mathrm{~V})$ experts (2), finance experts (2), ESCO representatives (5), market analysts (3), procurement framework representatives (4), trade body representatives (1), procurement experts (2), local authority representatives (2) and policymakers (2). Interviews were recorded and transcribed, except in cases where topics were commercially sensitive. Since only ten companies responded to the survey, it was not possible to derive a reliable quantitative estimate of the size of the UK market in 2014. Reliable estimates of market size are also not available from documentary sources. Primary reliance is therefore placed on the interview results.

The paper is structured as follows. The first section introduces the different types of energy service contract, followed by a brief history of energy service contracts in the UK, an overview of the current market status and a summary of the drivers and barriers to market growth. The paper then provides an overview of the companies currently operating in the UK and their different business strategies, followed by a review of market activity in different sectors - paying particular attention to the health sector and local authorities. The paper concludes by highlighting the enabling role provided by intermediaries and the limitations of the contracting model.

\section{Types of energy service contract in the UK}

Various definitions of energy service contracting have been proposed (Vine et al. 1999), but few satisfactorily describe the diversity of contractual arrangements that are available or the range of activities involved. Energy service contracts have been variously defined and categorised in relation to the nature of the energy services covered, the source of finance for new investment, the ownership of the relevant assets, the provision of guarantees for savings in energy consumption and/or costs and the degree to which control of energy services together with the associated risks is transferred to the contractor (Lay et al. 2009; Sorrell 2007). But there is little consensus on which combination of these distinguishes energy service contracts from more conventional market relationships. Also, the terminology used varies from one country to another, as does the types of contract available.

In a conventional 'design and build' project, the contractor is responsible for design, specification, construction and commissioning, and is paid on project completion. The contractor may be liable if the equipment does not work or does not perform to specification, but the contractor is not involved in operating the equipment and has neither the incentive nor the means to optimise equipment performance subsequent to project delivery. In contrast, an energy service contract establishes a link between contract payments and equipment performance and schedules these payments at intervals over a longterm period (typically, a minimum of 3 years). This provides the contractor with a long-term responsibility for ensuring and maintaining equipment performance (payment by results), with much of the performance risk of the relevant equipment being transferred to the contractor. The key to energy service contracts is therefore the performance incentives it provides, with contract payments commonly being linked to the energy and cost savings achieved. In addition, such contracts frequently (though not always) include performance 
guarantees, where the ESCO guarantees to deliver particular levels of energy or cost savings.

\section{Two types of energy service contracts}

As illustrated in Fig. 1, it is useful to distinguish between

- Energy supply contracts (ESCs) that primarily focus upon the delivery of 'useful energy streams' (e.g. steam, hot water and electricity) at a unit cost $(\mathfrak{f} / \mathrm{kWh})$ below an agreed baseline; and

- Energy performance contracts (EPCs) that primarily focus upon the delivery of 'final energy services' (e.g. heating, lighting, refrigeration) at an annual energy cost ( $\mathfrak{f})$ below an agreed baseline.

Both types of contract deliver energy savings through improving the efficiency of primary or secondary conversion equipment such as boilers and lights, preserving heat, momentum or materials in the associated passive systems such as buildings, or reducing demand for final energy services such as illumination (Cullen and Allwood 2010). EPCs generally provide greater incentives to reduce energy demand than ESCs, ${ }^{1}$ but the boundaries between the two are blurred and contracts vary in the number of energy-related technologies and services that they cover and the degree to which they cede control of those technologies and services to the contractor. A more common term for ESCs in the UK is contract energy management which typically involves the delivery of steam or hot water to a medium-sized site ('taking over the boiler house') often in association with CHP investment. EPCs are more commonly used for public sector buildings and usually involve the guarantee of energy cost savings, the finance of investment from those savings and the inclusion of detailed provisions for monitoring and verification. The EU Energy Efficiency Directive (Council of the European Union 2012) has sought to standardise the definition of EPCs as follows:

...Energy performance contracting means a contractual arrangement between the beneficiary and the provider of an energy efficiency improvement measure, verified and monitored during the whole term of the contract, where investments...in that

\footnotetext{
${ }^{1}$ If ESCs primarily charge for delivered useful energy, they may provide little incentive to reduce energy demand.
}

measure are paid for in relation to a contractually agreed level of energy efficiency improvement or other agreed energy performance criterion, such as financial savings... (Council of the European Union 2012)

\section{Dimensions of an energy service contract}

Sorrell (2005; 2007) argues that both ESCs and EPCs can be classified by the following:

- Scope: the number of useful energy streams and/or final energy services that are wholly or partially under the control of the contractor.

- Depth: the number of organisational activities required to provide those streams or services that are under the control of the contractor.

- Finance: the source of funds for new investment.

Scope relates to what technologies and systems are included in the contract (e.g. boilers, CHP, lighting, building and controls) while depth relates to how they are included (e.g. who has responsibility for design and engineering, financing, equipment specification, purchasing, installation, commissioning, operation, maintenance, monitoring, verification, and energy purchasing). Taken together, these influence the potential for cost savings, the distribution of risks and rewards and the associated transaction costs (Sorrell 2005). Comprehensive energy service contracts are broad and deep, providing the contractor with extensive control of the majority of useful energy streams and final energy services on one or a group of sites. However, it is possible to have contracts that are broad and shallow, as well as those that are narrow and deep.

The source of finance may include working capital provided by the client or by the ESCO, loans from financial institutions and equity from risk investors. Of particular importance is whether the investment is primarily financed through debt taken on by the client and hence appears on the client's balance sheet, or whether the investment is financed by the ESCO (DECC 2014b; Fawkes 2007). The latter may be unsuitable for small ESCOs since additional projects increase leverage-unless subcontractors can take on the debt. With larger projects, the ESCO may join with providers of risk capital and possibly the client to form a 'special purpose 
Fig. 1 Energy supply versus energy performance contracts

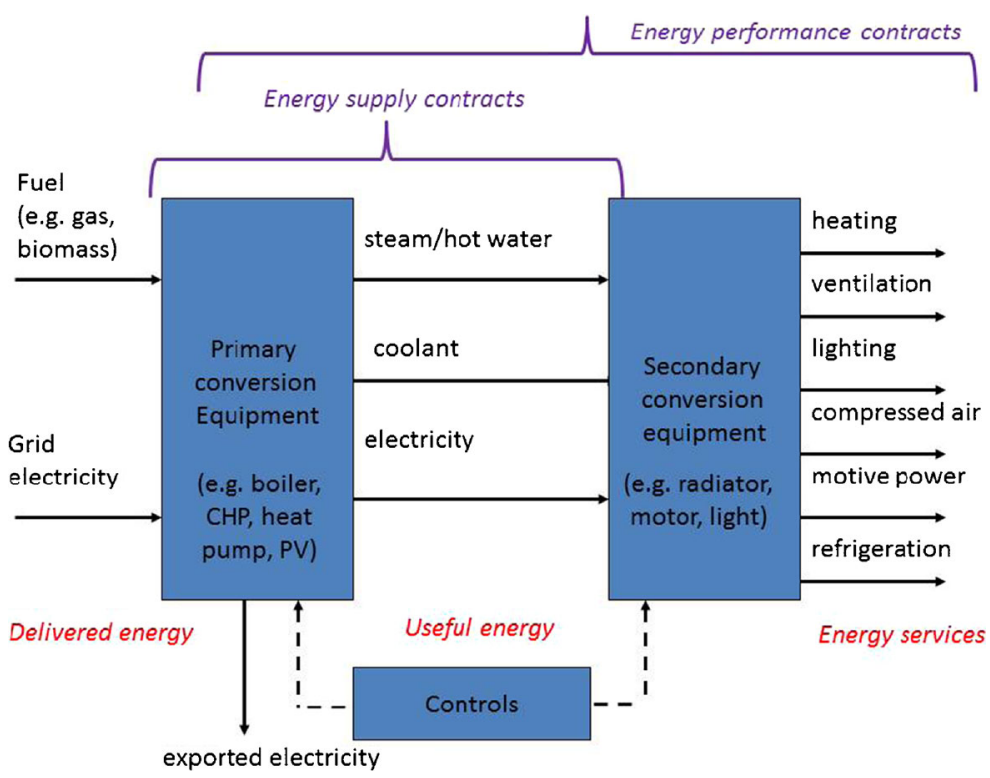

or more ESCO to develop projects before agreeing targets (partner bidding). The former approach encourages competition and hence value for money, but may also entail higher costs for the ESCOs and miss more ambitious opportunities. The latter approach can foster innovation and trust as well as helping clients to identify potential savings, but it can also limit competition at an early stage of the procurement process. This is where dedicated intermediaries can be useful in helping clients to identify projects and estimate target savings prior to going to tender.

\section{History of energy service contracts in the UK}

The UK energy service contracting market dates back to 1966, when Associated Heat Services (AHS) (Fawkes 2007) was set up by the National Coal Board to outsource the management of boiler houses (Fawkes 2007; Hannon 2012; Iqbal 2009). ${ }^{3}$ The market grew slowly up to the early 1980 s when it was characterised by a growing number of companies offering energy supply contracts ('contract energy management'), primarily to industrial sites. The market leaders were Emstar, formed by Shell in 1982, and BP Energy which followed in 1983 (Fawkes 2007). Heat supply contracts allowed

\footnotetext{
${ }^{3}$ In fact, the model dates back to the eighteenth century when Boulton and Watt used a form of 'shared savings' contracts to commercialise the Watt steam engine in coal mines (Crump 2007).
} 
Table 1 Issues covered by the terms of an energy service contract

\begin{tabular}{|c|c|}
\hline Area & Issues \\
\hline New equipment & Specification, selection, cost, responsibility for installation and commissioning \\
\hline Equipment ownership & Rights during and after contract, buyback provisions \\
\hline Maintenance & Division of responsibilities, monitoring \\
\hline Operation & Division of responsibilities, monitoring, coordination \\
\hline Performance and quality standards & $\begin{array}{l}\text { May range from pressure and temperature in the case of steam supply to complex } \\
\text { mix of comfort standards in the case of building energy services (e.g. temperature, } \\
\text { lighting levels, air exchange, user control) }\end{array}$ \\
\hline Reliability standards & $\begin{array}{l}\text { Maximum downtime, provisions for immediate and backup service in the event } \\
\text { of malfunction }\end{array}$ \\
\hline Service standards & Acceptable parameters for temperature, lighting, air exchange and other factors \\
\hline Monitoring and verification & $\begin{array}{l}\text { Methods for monitoring and verifying energy provision, consumption and savings, } \\
\text { including the use of standardised protocols }\end{array}$ \\
\hline Calculation of cost savings & $\begin{array}{l}\text { Baseline energy consumption and operating conditions, assumptions, formulae, } \\
\text { adjustment protocols }\end{array}$ \\
\hline Pricing and payment provisions & Fixed and variable components of pricing, guarantees to client, division of savings \\
\hline Adjustment to external changes & Adjustment to inflation, changes in energy prices and other factors \\
\hline Provisions for early termination & Buyout provisions, compensation, equipment removal provisions, restoration of facility \\
\hline Other & Insurance, dispute resolution, penalties for contract breach, force majeure, etc. \\
\hline
\end{tabular}

Source: Based on Hansen and Weisman (1998)

engineering companies to diversify their offerings to include finance and other 'value-added' services and thereby grow their market share. Over time, these contracts became more sophisticated and extended to a wider range of utilities (e.g. cooling, industrial gases, water), and they continue to dominate the UK market today (Fawkes 2007; Marino et al. 2010).

The EPC business model was imported from the US in the 1980s, with the Utility Management Company being the first to offer EPCs (Fawkes 2007). These took some time to become established, partly because the cheap sources of public finance that drove the US market were largely absent in the UK. But a number of developments, including changed regulations on the use of external financing by local authorities (Fawkes 2007; Grout 1997; Sorrell 2005), began to open up the UK public sector. The 1980s also saw some consolidation in the UK market, with AHS merging with Emstar in 1989 and subsequently being taken over by Dalkia (a subsidiary of Veolia Environnement) (Fawkes 2007; Iqbal 2009).

Market growth in the 1990s was partly driven by the diffusion of CHP and partly by the increasing tendency for organisations to outsource non-core services. The latter was particularly important for IT, but an increasing range of energy services were affected by this trend. The 1990s also saw the growth of 'facilities management' (FM) contracts that encompassed a range of activities such as security, fire safety, maintenance and cleaning, but rarely extended to energy services. Declining energy prices in the 1990s reduced interest in energy efficiency, thereby negatively affecting energy service contracts, but the ongoing liberalisation of gas and electricity markets created new opportunities for ESCOs to engage in energy purchasing.

In the early 2000 s the market changed again. Revisions to the electricity trading arrangements negatively impacted the market for small-scale generation and hence that for energy supply contracts (Hannon 2012). On the other hand, gas and electricity prices rapidly increased after $2003,{ }^{4}$ improving the economics of energy efficiency and strengthening the incentive for clients to outsource energy services. These incentives were enhanced by an increasing range of policies aimed at improving energy efficiency and reducing carbon emissions, such as the Climate Change Levy and the Climate Change Agreements (Ekins 2010).

\footnotetext{
$\overline{{ }^{4} \text { Between } 2004}$ and 2011, UK non-domestic electricity prices rose by around $115 \%$, and non-domestic gas prices rose by around $95 \%$, compared with general price inflation of $22 \%$.
} 
The 2008 global economic crisis put a halt to market expansion as lending criteria tightened and levels of investment fell dramatically (Marino et al. 2010). But the market began to recover after 2012, particularly in the public sector.

\section{Drivers and barriers to energy service contracts in the UK}

Our interviewees consistently reported that the UK market had grown modestly since 2012 and that this growth was continuing through to the end of 2014. The majority also observed that the fastest growing market was in the public sector, and the primary reason for this was the introduction of public procurement frameworks (PPF) - such as the Carbon and Energy Fund (CEF) in the health service and the RE:FIT initiative in London. These frameworks act as specialised intermediaries between client and ESCOs, assisting clients in the process of contract negotiation as well as employing standardised templates for contracts and invitations to tender and bundling multiple sites within a single contract (Bleyl et al. 2013). By such means, the frameworks lower transaction costs, reduce procurement times (e.g. to 3 to 6 months) and extend the contracting model to smaller sites such as primary schools.

Slower market growth was reported in the commercial and industrial sectors, but definitional problems and the reluctance of contractors to reveal relevant information make it very difficult to estimate the overall market size. Marino et al. (2010) estimated a UK ESC market of $£ 350$ million/year in 2009, and an EPC market of $£ 55$ million/year-and our interviews strongly suggest that the market has grown since that date. Fawkes (2007) provides an earlier estimate of $£ 500-750$ million for both types of contract, but much depends on which activities are included. While ESCs typically involve larger capital investments, the market for EPCs is growing more rapidly. The market in the UK is larger than in most European countries (Bertoldi et al. 2014; Marino et al. 2010), but that is partly due to the relative size of the UK economy. Comparison between countries is difficult, however, because the size of the market in different countries has not been estimated on a consistent basis. ${ }^{5}$

Interviewees highlighted a number of drivers of market growth, but found it difficult to assess their relative importance. On the 'market' side, the drivers mentioned most often by interviewees were (a) increasing competition and diversification within the energy service market, including the emergence of independent ESCOs; (b) growing interest from utility companies in the energy service business model - partly as a response to slow demand growth, changing regulations and a rapidly shifting electricity supply mix (Chazan 2014; Energyspectrum 2014); (c) rising energy prices encouraging greater management attention to energy efficiency; and (d) easier availability of low-cost finance for energy efficiency investment (for example from Salix Finance, ${ }^{6}$ London Energy Efficiency Fund and Sustainable Development Capital LLP).

'Policy' drivers appeared less important than market drivers, but several interviewees highlighted the incentives for both low-carbon energy supply (e.g. feed-in tariffs and renewable heat incentive) and demand response (e.g. the UK capacity market) which had encouraged ESCOs to extend their range of activities (DECC 2014a). ${ }^{7}$ Interviewees also highlighted the increased availability of public finance for low-carbon investment, such as from the UK government's Green Investment Bank and various EU initiatives.

Other drivers mentioned include organisational innovations and the growing use of performance-based business models by equipment and capital goods manufacturers (Philips 2014); the inclusion of energy services and performance incentives within broader facility management contracts; and the greater breadth and increased stringency of climate policy, including new initiatives such as the Carbon Reduction Commitment.

Interviewees also identified numerous barriers to energy service contracts, many of which have been highlighted by earlier studies (Bertoldi et al. 2014; Garnier 2013b; Sorrell 2005, 2007). These are summarised in boxes 3 and

\footnotetext{
$\overline{5}$ Bertoldi et al. (2014) and Marino et al. (2010)) provide overviews of the market within each EU Member State, but these are based upon national-level assessments that use different definitions and measures of energy service contracts.

${ }^{6}$ Salix is a not-for-profit company with funding from the UK government providing interest-free loans to the public sector to improve energy efficiency and reduce carbon emissions.

${ }^{7}$ The combination of demand reduction, demand response and distributed generation is now termed 'D3' by the UK government (DECC 2014a).
} 
4. However, the relative importance of these barriers varies between sectors and has changed over time. For example, pervasive split incentives provide the biggest obstacle to contracting within the commercial office sector, but are much less important within the public sector. In contrast, business risk appears the dominant concern in industry. Awareness of the nature and benefits of contracting appears to have substantially increased over the last decade, while concerns about job losses and contractual risks appear less prominent and low-cost financing is more readily available. Few of our interviewees identified financing as a major obstacle:

...if you have a viable business plan with robust $\mathrm{M} \& \mathrm{~V}$, you should not have any trouble accessing finance... ${ }^{8}$

Box 1: Incentives for organisations considering energy service contracts

- We need to save money: Aim to reduce energy costs and capture additional benefits such as reduced labour and maintenance costs, improved comfort and improved worker productivity.

- We need to focus: Prefer to concentrate attention on core competences and to outsource non-core activities.

- We need new kit: Need to replace or upgrade key items of energy-related equipment, owing to the age of plant, deterioration of efficiency, poor reliability and other concerns.

- We need finance: Aim to invest in new equipment while avoiding additional debt.

- We need to reduce risk: Aim to offload equipment performance and other risks to parties that are better able to manage them.

- We need better skills: Aim to access expertise and skills that are not available in-house, perhaps as a consequence of downsizing or of the retirement of key personnel.

- We need to comply: Aim to comply with health, safety and environmental regulations, but are challenged by their increasing complexity and stringency.

- We need to be green: Aim to demonstrate visible improvements in environmental performance and carbon emissions - especially for larger organisations that are subject to policy incentives or sensitive to investor and consumer pressure.

Source: Stakeholder interviews conducted during 2014-2015 and Sorrell (2005).

Box 2: Obstacles to organisations considering energy service contracts

\section{Information}

$\overline{{ }^{8} \text { Interview with }}$ an ESCO representative, 2015.
- We have not heard of it: Lack of awareness of the existence of contracting and the opportunities it offers.

- We do not understand it: Insufficient understanding of what contracting involves.

- We are efficient already: Lack of awareness of the opportunities for reducing energy costs.

- We think there is a catch: Distrust of the 'something for nothing' nature of contracting.

- We do not know our own costs: Inadequate energy monitoring and cost accounting, making it difficult to assess opportunities, draw up invitations to tender and appraise contractual offers.

- We have heard that ESCOs rip you off: Reports of bad experience with energy service contracting, creating a bias against it even when those reports have little foundation.

Split incentives

- We will not get the savings: Split of responsibility for energy costs between individuals, departments or organisations (e.g. landlord-tenant) reducing the financial incentive for contracting.

Risk

- We do not want to commit: Uncertainty over long-term business prospects leading to reluctance to enter into longterm contracts.

- We do not want to lose control: Concern about equipment reliability and production continuity leading to a preference for in-house control and a distrust of contractual guarantees.

- We can do it better: Preference for in-house energy management, even when current performance is poor and financing problematic.

Transaction costs relative to energy cost savings

- We have other priorities: Management focus on strategic priorities leading to neglect of energy saving opportunities ('... either I use my money to buy a new cancer ward with more beds, or I reduce our energy bills...'a).

- We are not interested: Small share of energy in total costs encouraging neglect of energy saving opportunities ('.. energy bills represent less than $3 \%$ of my budget. If I want to save money, I sack people..., ${ }^{\text {b) }}$.

- We do not have the time and skills: Lack of management time and specialised knowledge preventing the investigation and negotiation of contracts - despite the potential of such contracts to free-up staff time over the longer term.

${ }^{a}$ Interview with procurement framework representative, 2015.

${ }^{\mathrm{b}}$ Interview with procurement framework representative, 2015.

Source: Stakeholder interviews conducted during 2014-2015 and Sorrell (2005).

\section{Providers of energy service contracts in the UK}

Our interviews and documentary searches indicate that there were at least 50 companies and cooperatives offering energy service contracts in the UK in 2014 
(Table 2). At least 35 ESCOs had a national or international focus, of which 15-20 were relatively active, 510 were 'large players', 25 offered EPCs in some form and 22 were participating in the public procurement frameworks. In addition, there were at least six community ESCOs and at least nine local authority ESCOs engaged in supplying energy in their local areas (Hannon et al. 2015). The overall picture was one of fluidity, with regular changes in the number and ownership of companies, and diversity, with considerable variation in the origin, expertise and size of companies, and in the types of contract offered, sectors targeted, technologies installed and savings achieved. The largest contractors were subsidiaries of multinationals such as Dalkia and Honeywell, but the last few years had seen the emergence of smaller and more specialised ESCOs such as ANESCO. Utilities such as EdF and EON were becoming more important players, despite energy service contracts forming only a small part of their overall business, while local authorities were entering the energy service market as providers, although their activities were primarily focused upon heat and electricity supply (Hannon et al. 2015).

With such a diversity of companies and activities, the boundaries of the 'sector' are unclear and there is no single trade association. In 2014, ten of the companies listed in Table 2 were members of the Association for Decentralised Energy (formerly the CHPA), seven were members of the Alliance for Energy Management
(AfEM), ten were members of the Energy Systems Trade Association (ESTA) and several were not affiliated to any association. Since none of these trade associations focus solely upon energy service contracting, they may not provide an effective lobby in its favour.

\section{Equipment suppliers}

Some of the biggest market players are subsidiaries of international equipment suppliers, such as Honeywell and Johnson Controls, and have sufficient scale to provide their own financing. Suppliers of primary conversion equipment (e.g. Veolia) offer energy supply contracts focused upon CHP, suppliers of secondary conversion equipment (e.g. Philips) offer specialised 'pay as you 'save contracts for technologies such as lighting (Philips 2014) and suppliers of building energy management systems (e.g. Johnson Controls) offer bespoke performance contracts using a range of technologies. But diversification is the norm and companies are increasingly combining these approaches. For example, it is common for building control providers to install more efficient boilers and CHP while companies specialising in CHP are moving into building controls.

\section{Utilities}

Subsidiaries of energy utilities see the energy service market as a way of diversifying their business and
Table 2 Companies providing energy supply and energy performance contracts in the UK in 2014

\begin{tabular}{ll}
\hline Origin & Main companies \\
\hline Equipment suppliers & Doosan Babcock, Finning, General Electric, Honeywell, \\
& Johnson Controls, Philips Lighting, Siemens, Veolia (Dalkia) \\
Utilities & EDF, E.On, British Gas Business, SSE \\
Construction/engineering & Bilfinger, Bouygues, Imtech, Interserve, Kier, Skanska, \\
companies & Willmott Dixon \\
Facilities management/ & Carillion, Cofely, ENER-G, Mitie, Norland, Schneider Electric \\
integrated services & EuroSite Power, Utilitywise \\
Procurement agency & Ameresco, Anesco, Breathe Energy, Cynergin, Self Energy, \\
Independent ESCOs & Utilyx, Vital Energi \\
& Aberdeen Heat and Power Company, Barkantine Heat and Power \\
Local authority & Company, Birmingham District Energy Company, Coventry \\
& District Energy Company, Enviroenergy, Leicester District \\
& Energy Company, Pimlico District Heating, Southampton \\
Geothermal Heating Company, Thameswey Energy
\end{tabular}


adding value to their core markets. Their level of involvement varies widely, with British Gas being one of the most successful and with several utilities actively participating in the public procurement frameworks (Table 4). But the provision of energy services presents a different business challenge to energy supply and requires new competencies and skills, so entering this market can be challenging. One response is to buy up specialised energy efficiency companies, but several interviewees questioned whether utilities fully understood the complexity involved:

...My view is that [utilities] know they have to do something but they don't know what to do and they don't really understand it because, at the end of the day, [...] they are run by people who understand energy supply but don't understand energy efficiency. I think they understand [the need to change], but it's like steering a super-tanker. ${ }^{9}$

\section{Facilities management companies and independent ESCOS}

Facilities management companies such as Cofely (GDF Suez) and MITIE are increasingly active in the energy services area, building upon their extensive experience with outsourcing more generally-particularly in the USA (Goldman et al. 2005; Larsen et al. 2012a, b). Such companies have the capacity to cover a wide range of contracts and may have different divisions targeting different markets.

Independent ESCOs are typically smaller and newer and tend to intermediate between technology providers, maintenance contractors, legal firms, financiers and other organisations (DECC 2014b; Garnier 2013a). Much of the engineering work is subcontracted to specialist companies who guarantee equipment performance and sometimes also provide financing. The 'risk boundary' differs between contracts and some ESCOs may outsource nearly every step of the process to other companies - thereby minimising their risk exposure. Their business model relies upon cooperation with established technology providers with a proven track record and a solid credit rating since '...they are the only ones that can give a guarantee that's worth it..., 10

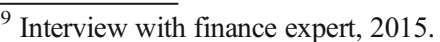

${ }^{10}$ Interview with finance expert, 2015.
}

Local authorities and community ESCOs

Local authorities are increasingly engaged in energy projects, with a proportion of these involving the provision of district heating through energy supply contracts (Hannon et al. 2015; Nolden and Sorrell 2015). The two main business models for local authorities are: first, to establish an arm's-length, not-for-profit ESCO that is owned and operated by the local authority; and second, to collaborate with an existing ESCO to establish a special purpose vehicle. Notable examples of the former include Aberdeen Heat and Power (Aberdeen City Council) and Thameswey Energy (Woking Borough Council), while notable examples of the latter include Birmingham District Energy Company Ltd (Cofely GDF Suez) (Hannon et al. 2015; Hawkey et al. 2013).

Local authorities may also act as sponsors for various types of community ESCO, but the majority of these are primarily engaged in small-scale renewable energy supply rather than energy efficiency.

Overall, this review demonstrates that there is no single market for energy service contracts in the UK and no unified set of market actors. Instead, it is more useful to subdivide the market into particular segments, such as the market for energy performance contracts in public sector buildings. Each market segment appears relatively competitive, with no single dominant players.

\section{Markets for energy service contracts in the UK}

The contracts offered by UK companies vary widely in size: for example, from a capital investment of around $£ 50$ thousand for sites bundled into a multisite contract, up to $£ 25$ million or more for large-scale CHP and heat distribution. While traditional energy supply contracts dominate overall investment, the number of performance contracts is growing, the boundaries between supply and performance contracts are becoming less clear (many contracts include both) and an increasing number of contracts incorporate renewable energy.

Our interviews indicate that most companies would not consider individual clients with a minimum annual utility bill of less than $£ 500$ thousand, although the smaller, independent ESCOs have a lower threshold for contract size. Energy supply contracts are more common in industrial sites and in non-domestic sites suitable for CHP (e.g. hospitals), while energy performance contracts are more common in non-domestic 
buildings. The latter typically focus upon wellestablished, low-risk technologies such as lighting (especially LEDs), HVAC, voltage optimisation and building controls and tend to use low-cost measures with short paybacks to subsidise more capital intensive measures with longer paybacks. EPCs rarely extend to building envelope measures and are not driving the 'deep retrofits' of buildings - partly because there are so many low-cost energy-saving opportunities still available, but also because EPCs appear less suitable for measures with low rates of return. Contract lengths vary from a minimum of 3 years to a maximum of 25 years, although most are between 5 and 10 years. Energy savings are typically between 10 and $30 \%$ of baseline and typically involve capital investments of $£ 0.5-5$ million.

\section{Industrial markets}

Industrial contracts primarily focus upon heat supply and on-site electricity generation through CHP. As well as delivering useful energy at a specified unit cost, these contracts must meet high standards of reliability, since interruptions in energy supply can damage or stall industrial processes and have a major impact on profitability. Contracts that 'take over the energy centre' may also provide industrial gases, cooling and water but rarely extend to industrial processes - both because the contractor has less expertise than the clients with these technologies and because the clients usually wish to retain control over their core activities. Performance contracts are less common in industry, although some ESCOs provide guaranteed savings for specific services such as compressed air, warehouse lighting or voltage optimisation. The continuing decline in UK industrial capacity constrains market growth in this sector, and the potential for energy savings is typically less than in public and commercial buildings:

...What we're seeing within the manufacturing sector is that a lot of the low-hanging fruit, the things you would typically look for when you step on-site for the first time have already been done. They're looking for more innovative technologies such as waste-to-energy, on-site generation, modern control systems, anything like that that would give them an additional
5-10\% saving on top of what they have already achieved...

Many of the industrial sites targeted by ESCOs are of intermediate size with moderate energy intensity. This is because large, energy-intensive sites tend to have sufficient in-house expertise to exploit cost saving opportunities, while smaller, less energy-intensive sites may miss those opportunities but the potential savings are too small to make contracting viable (Sorrell 2005). As a consequence, SMEs remain largely untapped to date, although some ESCOs are beginning to enter this market through energy purchasing. By procuring energy for several similar SMEs, it is possible to guarantee lower energy bills through bulk purchasing. Once a trusted relationship has been established, further demand reduction services may be included in the energy service package.

\section{Commercial sector markets}

While there are numerous examples of ESCs in the UK commercial sector, the take-up of EPCs is much lower than in the public sector. This parallels the situation in the USA, where industry and commerce account for only $15 \%$ of the US EPC market and commercial offices only $6 \%$ (Larsen et al. 2012a, b). The UK market includes small-scale CHP contracts in hotels and leisure facilities, larger supply contracts in airports and data centres that also extend to lighting, ventilation and other services, and an increasing number of contracts in private schools that encompass both energy supply and energy demand. The combination of ageing infrastructure, access to finance and a desire to appear 'green' has made private schools a growth market. Contracts in all areas increasingly include solar PV and biomass, and use the revenue derived from feed-in tariffs and the renewable heat incentive to cross-subsidise investments in energy efficiency.

Despite the size of the relevant estate, there are relatively few contracts in the retail sector-largely because retailers have large and sophisticated energy management teams that manage multiple sites, and because they are reluctant to cede control over critical equipment such as refrigeration. The largest potential market is commercial office space, but here, the barriers to energy service contracts appear particularly large. Commercial

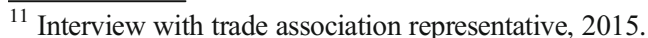


companies have a higher credit risk than the public sector and shorter time horizons, which make them reluctant to sign contracts of more than 5 years duration. But a greater problem is that the majority of office space is leased, creating the well-known problem of split incentives (Sorrell et al. 2004). Landlords are reluctant to invest since tenants will reap the benefits in terms of lower energy bills, energy-efficient buildings do not attract a significant rental premium (despite the use of Energy Performance Certificates) and tenants lack the ability and/or incentive to invest since their tenure may be relatively short. This leads to widespread scepticism of the potential for EPCs in this sector:

...You can't do any EPC in commercial office space. It doesn't work... EPC works in a certain market segment and that is primarily the public sector. It doesn't work in any other market segment. In the US when they tried to take into another segment it failed miserably... ${ }^{12}$

Several interviewees highlighted the potential of alternative policy initiatives and business models to overcome these barriers - as summarised in box 3. These ideas draw upon recent experience in the USA and Australia (Dixon et al. 2008; Fawkes 2013; Kim et al. 2012; Sayce et al. 2009; Supple 2010) and were considered by one interviewee to represent: '...a huge flowering of innovation and change that will completely eclipse the EPC market in time.... ${ }^{, 13}$ However, the UK has yet to develop an equivalent of PACE or MEETS; green leases have attracted only limited interest (Dixon et al. 2014), and a policy initiative based upon on-bill financing (the 'Green Deal') was not a success (Rosenow and Eyre 2015; Rosenow and Sagar 2015). More generally, energy efficiency improvements in the commercial and other sectors are hindered by the difficulty financiers have in recognising energy cost savings as security for loans:

...Energy efficiency projects do not yet meet the requirements of capital markets. The industry is too disaggregated. No two projects or contracts are alike. Securitisation is not practical or possible under these circumstances. Say you have 1000 energy efficiency projects. Standard and Poor

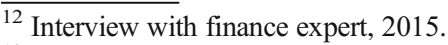

${ }^{13}$ Interview with finance expert, 2015.
}

would have to read 1000 documents to assess the risk. Fees won't pay for that level of review... ${ }^{14}$

This problem has led to the establishment of a European Investor Confidence Project (ICP) which seeks to standardise how energy efficiency projects are engineered, documented, evaluated and implemented through the development of standardised protocols and crediting processes. The aim is to certify projects as 'investor ready', thereby reducing transaction costs, improving confidence in reliability of energy savings and allowing investors to package investments for trade in secondary markets. As with the initiatives in box 3, the ICP has yet to become established in the UK. But some combination of these different approaches is likely to be required in the commercial office market, since the EPC model alone will not unlock the potential.

Box 3: Emerging models for energy efficiency investment in the commercial office sector

On-bill finance $(\mathrm{OBF})$ : More of a collection mechanism than a type of financing, with the repayment of capital (from utilities, the state or third parties) taken from electricity and gas bills. The total post-retrofit utility bill should not exceed the pre-retrofit bill, and repayment obligations are tied to the property and not the owner. This mechanism has proved successful in the USA, but the UK Green Deal policy - which was modelled on the US experience - proved unsuccessful and was withdrawn in 2015.

Property Assessed Clean Energy financing (PACE): A means of financing building renovations through the use of bonds offered by local governments to investors. The funds raised are used to finance energy efficiency investments that are then repaid via annual assessments on property taxes. The loan is secured to the building and not to the owner or tenant.

Green leases: Leases that give the landlord and tenant responsibilities with regard to the sustainable operation of a property - for example, energy efficiency measures, waste reduction/management and water efficiency. 'Darker green' provisions include energy efficiency targets with penalties for non-compliance, such as increased rents or rent reductions.

Measured Energy Efficiency Transaction Structure (MEETS): Developed by Energy RM and used in Seattle, this relies upon a 'dynamic' metering system that provides estimates of energy savings that have been approved by the local utility. The client pays an agreed price per unit saved (MWh) on a 20 -year agreement similar to a power purchase agreement. Repayment is linked to the building rather than the occupier.

\footnotetext{
${ }^{14}$ Michael Eckhart Managing Director and Global Head of Finance and Sustainability. Quoted in http://www.greenbiz.com/ article/can-new-standard-spur-new-investment-green-buildings
} 
Source: Dixon et al. (2008); Fawkes (2013); Kim et al. (2012); Sayce et al. (2009); Supple (2010); Stakeholder interviews 2014-2015

\section{Public sector markets}

In most countries, the public sector provides the largest market for energy service contracts, owing to its large and diverse estate (e.g. hospitals, offices, schools, libraries, leisure centres), low credit risk, long time horizons, security of tenure, targets to improve energy performance and, in some cases, access to low-cost financing. The UK public sector market has taken longer to develop than in the USA and many European countries (Bertoldi et al. 2014; Garnier 2013b; Goldman et al. 2005; Larsen et al. 2012a, b), but the recent introduction of public procurement frameworks (PPF) for energy service contracts has significantly increased activity. These frameworks are the most important development in the UK market in the last ten years.

Framework agreements are a common feature of UK public sector procurement and set out the terms and conditions under which purchases or contracts ('calloffs') can be made throughout the period of the agreement (typically 4 years). The agreement is advertised in the Official Journal of the European Union (OJEU), but the individual call-offs are not - thereby avoiding the associated time delays and costs. The new PPF involve a standardised process for developing energy service contracts that comply with EU regulations and allows a number of pre-qualified ESCOs to bid. The PPF also establish intermediary organisations to facilitate the contracting process and use standardised templates and contracts. There are five frameworks currently in operation: two developed by local authorities (RE:FIT and PEPC) and three developed for the National Health Service (NHS) (CEF, Essentia and Ecovate) - although each are being extended beyond their core sectors. Table 3 summarises these frameworks while Table 4 indicates the companies participating within each. Their importance is reflected by the number of contracts that they have established in a short space of time, the growing interest in their approach by a range of public sector organisations the development of model contracts and guidance notes by the UK government that are based upon those used by RE:FIT (DECC 2015a, b).

Procurement of an energy service contract typically requires significant time, resources, know-how and expertise on behalf of the client. These may not be readily available, or may be expensive to acquire, with the procurement process being further complicated by the need to coordinate departments with competing interests. The intermediaries established by the PPF can reduce these problems by assisting clients in feasibility studies, structuring finance, preparing tender documents, evaluating proposals, providing monitoring and verification and so on. At the same time, the intermediaries can help contractors to better understand client needs and assist in mediating conflicts (Bleyl et al. 2013; Mourik et al. 2014).

As an illustration, the Programme Delivery Unit (PDU) set up by the RE:FIT framework helps clients to benchmark their energy consumption, identify investment options, estimate potential energy and carbon savings, develop project briefs and conduct competitions to select their preferred contractor. It significantly lowers transaction costs for the client by providing expert assistance along with templates for each project stage, and encourages learning by providing case studies and facilitating access to previous RE:FIT participants to share knowledge. ${ }^{15}$ Such a process allows clients to benefit from the experience of previous projects, as well as streamlining the procurement process and minimising conflicts (Bleyl et al. 2013; Mourik et al. 2014). And since the intermediary is independent of the contractors, cost-effectiveness is increased. The CEF operates in a similar way:

...Traditionally public sector bodies would complete stand-alone procurement so contracts had to be purchased, consultants employed and contractors procured, and once it was complete all the knowledge was lost. Then, after construction, the schemes typically started to underperform due to a lack of finance, contractual awareness and knowledge if things didn't go as well as expected. The CEF was created as a place to capture knowledge and to simplify the process so could be repeated time and time again... ${ }^{16}$

Up to 2015, RE:FIT clients paid no cost for this facilitation process, thanks to subsidies from the local authority and the EU ELENA scheme, ${ }^{17}$ while clients

\footnotetext{
$\overline{15}$ RE:FIT website (http://refit.org.uk/).

${ }^{16} \mathrm{CEF}$ website (http://www.carbonandenergyfund.net/)

${ }^{17}$ Run by the European Investment Bank, the European Local Energy Assistance (ELENA) scheme covers up to $90 \%$ of the technical support costs needed to prepare, implement and finance regional sustainable energy projects.
} 
Table 3 Key features of UK public procurement frameworks for energy services

\begin{tabular}{|c|c|c|c|c|c|}
\hline Originator & $\begin{array}{l}\text { RE:FIT } \\
\text { Greater London } \\
\text { Authority }\end{array}$ & $\begin{array}{l}\text { P-EPC } \\
\text { Peterborough City } \\
\text { Council }\end{array}$ & $\begin{array}{l}\text { CEF } \\
\text { Countess of Chester } \\
\text { Hospital NHS } \\
\text { Foundation Trust }\end{array}$ & $\begin{array}{l}\text { Essentia } \\
\text { Guy's and St Thomas' } \\
\text { NHS Foundation Trust }\end{array}$ & $\begin{array}{l}\text { Ecovate } \\
\text { King's College } \\
\text { Hospital NHS } \\
\text { Foundation Trust }\end{array}$ \\
\hline Established & 2008 & 2013 & 2011 & 2012 & 2013 \\
\hline $\begin{array}{l}\text { Approved } \\
\text { contractors }\end{array}$ & 12 & 1 & 16 & 8 & 8 \\
\hline Main clients & $\begin{array}{l}\text { Public sector } \\
\text { organisations in } \\
\text { London (2008) and } \\
\text { England (2014) }\end{array}$ & $\begin{array}{l}\text { Local authority } \\
\text { premises }\end{array}$ & $\begin{array}{l}\text { NHS trusts and } \\
\text { universities }\end{array}$ & $\begin{array}{r}\text { NHS trusts and public } \\
\text { sector organisations }\end{array}$ & NHS trusts \\
\hline Achievements & $\begin{array}{l}200 \text { public sector } \\
\text { organisations in } \\
\text { London with over } \\
460 \text { buildings. } \\
£ 68.6 \text { million of } \\
\text { investment with } \\
\text { typical savings of } \\
15-20 \% \text { (up to } \\
47 \% \text { ) and payback } \\
\text { of 5-7 years }\end{array}$ & $\begin{array}{l}\text { First two phases with } \\
\text { ten buildings in total } \\
\text { completed with } \\
£ 4.4 \text { million } \\
\text { investment. Phases } \\
3-5 \text { include } 42 \\
\text { schools. Guaranteed } \\
\text { energy savings of } \\
20 \% \text { with a 15-year } \\
\text { payback }\end{array}$ & $\begin{array}{l}50 \text { NHS hospitals to } \\
\text { date. Target of } \\
\text { upgrading } 240 \text { over } \\
16 \text { years. Current } \\
\text { contracts amount to } \\
£ 100 \text { million in } \\
\text { capital value, } £ 20 \\
\text { million in savings } \\
\text { and over } 20 \% \text { in } \\
\text { energy savings (up } \\
\text { to } 50 \% \text { ) with } 15- \\
\text { 25-year payback }\end{array}$ & $\begin{array}{l}14 \text { NHS Trusts have } \\
\text { established EPCs } \\
\text { using the framework } \\
\text { with typical energy } \\
\text { savings of } 15-25 \% \\
\text { and average energy } \\
\text { saving of } 17 \%\end{array}$ & $\begin{array}{l}\text { Kings College NHS } \\
\text { Trust has established } \\
\text { an EPC-reducing } \\
\text { energy consumption } \\
\text { by } 9 \% \text { with } \\
11 \text { years payback, } \\
\text { removing £3.1 } \\
\text { million of backlog } \\
\text { investment }\end{array}$ \\
\hline
\end{tabular}

Note: Figures apply to early 2015 , but the market for each framework is growing rapidly.

of other PFEPCs pay around $4 \%$ of the capital value of the projects. All of the PPF appear increasingly successful, but they differ in their focus, scale and method of approach (Table 3). To illustrate, we summarise the two largest $-\mathrm{CEF}$ and RE:FIT.

The Carbon and Energy Fund $(C E F)$ is the oldest and largest framework in the UK and primarily operates in the health service - which has an annual energy bill of more than $£ 750$ million across 12,000 sites (2300 hospitals), ageing infrastructure and significant backlog maintenance (GIB 2014). The CEF funds, facilitates, manages and monitors complex energy infrastructure upgrades for large sites, including hospitals and, more recently, universities. The CEF combines the roles of framework agreement, intermediary and financier, since it is also an SPV with funding from the Green Investment Bank and other sources. Most CEF projects involve large scale CHP, boiler replacement, building management systems and some demand side investment, with a minimum project size of $£ 1$ million and typical size $£ 6$ million. On average, $4-6$ of its 16 pre-approved suppliers bid for individual projects, guaranteeing either unit price or energy cost savings of $20 \%$ or more over periods of $15-25$ years. The framework has completed or is processing more than 40 projects amounting to over $£ 200$ million in capital value and expects to double that figure over the next few years.

$R E: F I T$ was launched by the Greater London Authority (GLA) in 2008 and is now being extended throughout the UK public sector. The scheme was partly modelled on US experience, including the retrofit of the Empire State Building (GLA 2012). The framework uses EPCs with guaranteed savings and has a target of retrofitting $40 \%$ of London's public sector floor space by 2025 (GLA 2015). There are 12 approved contractors, of which 4-6 typically bid for a project. The average project involves capital investment of $£ 1$ million and delivers 15-20\% energy savings with a payback period of 5-7 years - primarily using established, low-risk technologies. In contrast to CEF, most RE:FIT projects are financed by clients taking on low-cost loans. The use of standardised contracts and involvement of the PDU can shorten the contracting process to as little as 8 weeks. Over 50 contracts had been signed up to summer 2015, involving 200 public sector bodies (e.g. local and central government, NHS, museums, schools) and over 400 buildings, and these are expected to reduce carbon emissions by $30 \mathrm{kt} \mathrm{CO}_{2} /$ year from an investment of $£ 63$ million (GLA 2012, 2015). A notable feature of 
Table 4 Companies participating in UK energy service procurement frameworks

\begin{tabular}{|c|c|c|c|c|}
\hline Company & $\mathrm{CEF}$ & RE:FIT & Essentia & P-EPC \\
\hline Ameresco (previously ESP) & $*$ & & & \\
\hline Bilfinger & $*$ & & & \\
\hline Bouygues & $*$ & * & & \\
\hline Breathe Energy (MCW) & $*$ & $*$ & $*$ & \\
\hline British Gas & & * & $*$ & \\
\hline Cofely & $*$ & $*$ & $*$ & \\
\hline Cynergin & $*$ & & $*$ & \\
\hline Doosan Babcock & $*$ & & & \\
\hline EDF & $*$ & $*$ & & \\
\hline ENER-G & $*$ & & $*$ & \\
\hline E.On & $*$ & $*$ & $*$ & \\
\hline Honeywell & & $*$ & & $*$ \\
\hline Imtech & $*$ & $*$ & $*$ & \\
\hline Kier & $*$ & & & \\
\hline Mitie & $*$ & $*$ & & \\
\hline Norland & & $*$ & & \\
\hline \multicolumn{5}{|l|}{ Schneider Electric ${ }^{\mathrm{a}}$} \\
\hline Skanska & & $*$ & $*$ & \\
\hline SSE & $*$ & & & \\
\hline Veolia (previously Dalkia) & $*$ & & & \\
\hline Vital Energi & $*$ & & & \\
\hline Willmott Dixon & & $*$ & & \\
\hline
\end{tabular}

CEF has procured three frameworks with a different mix of ESCOs in each

${ }^{\text {a }}$ Schneider Electric appears in the list as it was contracted through Ecovate to undertake an EPC at King's College Hospital in 2013

RE:FIT is the extension of the approach to schools via bundled, multisite contracts with a target of retrofitting over 200 schools in 3 years.

Overall, the procurement frameworks have catalysed the UK market for energy performance contracts and are expected to drive energy savings in the UK public sector for a number of years. The frameworks are similar to those emerging in other EU countries (e.g. Austria, Germany, Sweden) and demonstrate the importance of such intermediaries for enabling clients to access energy service contracts (Bleyl et al. 2013).

\section{Conclusions}

This article has summarised the status of the UK market for energy service contracts in 2014. There are three main conclusions. First, the UK market is large by European standards, experiencing modest growth, highly diverse, concentrated in particular sectors and types of site, and primarily focused upon established technologies with high rates of return. While energy supply contracts account for the larger share of investment, the market is increasingly shifting towards energy performance contracts. This market is proving successful in overcoming barriers to energy efficiency investment and is delivering significant cost savings to multiple clients. However, the range of clients is restricted, innovative technical solutions are largely absent and critical areas such as building fabric improvements remain largely untouched.

Second, the most important driver of market growth is the development of procurement frameworks for energy service contracts in the public sector. By acting as intermediaries between clients and contractors, these frameworks lower transaction costs, facilitate learning and are beginning to extend the contracting model to smaller sites. Previous literature has paid little attention to the role of intermediaries in this market, but the UK experience suggests that their role in the public sector is critical and deserves further investigation.

Third, the EPC model is struggling to become established in the commercial sector in general and the commercial office sector in particular, partly as a result of split incentives. To unlock this market, different business models, tenancy arrangements and/or policy initiatives are likely to be required-perhaps modelled upon recent developments in the USA and Australia (box 3).

Overall, the research suggests that there is considerable scope for expanding the current UK energy service market, particularly through the continued development of intermediary organisations such as public procurement frameworks that lower transaction costs for both contractors and clients. Policy efforts to improve building energy efficiency should therefore consider targeted support for such intermediaries, such as subsidising fees for public sector clients, as this could offer substantial returns. ${ }^{18}$ However, the high transaction costs of energy service contracting may still constrain its use to larger organisations and

\footnotetext{
${ }^{18}$ The EU Energy Efficiency Directive states that '... Member States or support the proper functioning of the energy services market... by enabling independent market intermediaries to play a role in stimulating market development on the demand and supply side...' (Council of the European Union 2012).
} 
to relatively cost-effective energy efficiency opportunities. If the goal is deep retrofits of buildings, targeting of small organisations or accelerated diffusion of innovative energy-efficient technologies, additional policies and business models are likely to be required.

Acknowledgments This research was funded by the Research Councils UK through their support for the Centre on Innovation and Energy Demand (Grant no. EP/KO11790/1).

Open Access This article is distributed under the terms of the Creative Commons Attribution 4.0 International License (http:// creativecommons.org/licenses/by/4.0/), which permits unrestricted use, distribution, and reproduction in any medium, provided you give appropriate credit to the original author(s) and the source, provide a link to the Creative Commons license, and indicate if changes were made.

\section{References}

Bertoldi, P., Boza Kiss, B., Panev, S., \& Labanca, N. (2014). ESCO Market Report 2013. European Commission Joint Research Centre. Italy: Ispra.

Bleyl, J. W., Adilipour, N., Bareit, M., Kempen, G., Cho, S. H., Vanstraelen, L. (2013). ESCo market development: a role for facilitators to play. ECEEE summer study proceedings, Belambra Les Criques, France.

Chazan, G. (2014). Crisis-hit European utilities square up to technological revolution, Financial Times.

Council of the European Union. (2012). Directive 2012/27/EU of the European Parliament and of the Council on energy efficiency, amending Council Directive 2009/125/EC and 2010/30/EU and repealing Directives 2004/8/EC and 2006/32/EC. Official Journal of the European Union, L315, $1-56$.

Crump, T. (2007). The age of steam. London: Constable and Robinson.

Cullen, J. M., \& Allwood, J. M. (2010). The efficient use of energy: tracing the global flow of energy from fuel to service. Energy Policy, 38, 75-81.

DECC. (2014a). D3: opportunities for integrating demand-side energy policies. London: Department of Energy and Climate Change.

DECC. (2014b). UK National Energy Efficiency Action Plan. London: Department of Energy and Climate Change.

DECC. (2015a). Contract guidance \& model contract - energy performance contract (EPC), in: Change DoEaC (Ed.), London.

DECC. (2015b). Guide to energy performance contracting best practices. London: Department of Energy and Climate Change.

Dixon, T., Bright, S., \& Mallaburn, P. (2014). Commercial property retrofitting: what does "retrofit" mean, and how can we scale up action in the UK sector? Journal of Property Investment \& Finance, 32, 443-452.
Dixon, T., McNamara, P., Hinnells, M., Bright, S., Langley, A., Woodford, L., Schiellerup, P., \& Bosteels, T. (2008). The greening of commercial leases. Journal of Property Investment \& Finance, 26, 541-551.

Ekins, P. (2010). UK energy policy and institutions. In J. Skea, P. Ekins, \& M. Winskel (Eds.), Energy 2050: making the transition to a secure low-carbon energy system (p. 2010). London: Earthscan.

Energyspectrum. (2014). The impact of distributed generation on the utility business model. Cornwall Energy.

Fawkes, S. (2007). Outsourcing energy management - saving energy and carbon through energy partnering. Aldershot: Gower Publishing Ltd.

Fawkes, S. (2013). Emerging models for energy efficiency financing, Only Eleven Percent.

Garnier, O. (2013a). Country report on identified barriers and success factors for EPC project implementation-United Kingdom. Transparence - increasing transparency of energy service markets, London.

Garnier, O. (2013b). European EPC market overview. Transparence-increasing transparency of energy service markets, London

GIB. (2014). A healthy saving: energy efficiency and the NHS - a market report by the Green Investment Bank. London: Green Investment Bank.

GLA. (2012). 400 public buildings set to be given an energy efficiency makeover saving millions off energy bills, Mayor's press release. London: Greater London Authority.

GLA. (2015). RE:FIT - putting our energy into reducing yours. London: Greater London Authority.

Goldman, C., Hopper, N., \& Osborn, J. (2005). Review of US ESCO industry market trends: an empirical analysis of project data. Energy Policy, 33, 387-405.

Grout, P. A. (1997). The economics of private finance initiative. Oxford Review of Economic Policy, 13, 53-66.

Hannon, M. J. (2012). Co-evolution of innovative business models and sustainability transitions: the case of the energy service company (ESCo) model and the UK energy system, Sustainability Research Institute, School of Earth and Environment and Energy Research Institute, School of Process, Environmental and Materials Engineering. Leeds: University of Leeds.

Hannon, M. J., Foxon, T. J., Gale, W. F. (2015). 'Demand pull' government policies to support product-service system activity: the case of energy service companies (ESCos) in the UK. Journal of Cleaner Production, 108 Part A, 900-915.

Hansen, S., Langlois, P., \& Bertoldi, P. (2009). ESCOs around the world: lessons learned in 49 countries. Lilburn, Georgia, USA: Fairmont Press.

Hansen, S. J., \& Weisman, J. C. (1998). Performance contracting: expanding horizons. Lilburn: Fairmont Press Inc.

Hawkey, D., Webb, J., \& Winskel, M. (2013). Organisation and governance of urban energy systems: district heating and cooling in the UK. Journal of Cleaner Production, 50, 22 31 .

Iqbal, A. (2009). United Kingdom, In: Hansen SJ, Langlois, P., Bertoldi, P. (Ed), ESCOs around the world: lessons learned in 49 countries (p. 27). Lilburn, GA: Fairmont Press.

Kim, C., O'Connor, R., K. B, Hochman, S., Liang, W., Pauker, S., Zimmerman, S. (2012). Innovations and opportunities in 
energy efficiency finance. Wilson, Sonsini Goodrich and Rosati, New York, USA.

Larsen, P. H., Goldman, C. A., \& Satchwell, A. (2012a). Evolution of the U.S. energy service company industry: market size and project performance from 19902008. Energy Policy, 50, 802-820.

Larsen, P. H., Goldman, C. A. and Satchwell, A. (2012). Evolution of the US energy service company industry: market size and project performance from 1990-2008. Ernest Orlando Lawrence Berkeley National Laboratory LBNL-5447-E.

Lay, G., Schroeter, M., \& Boiege, S. (2009). Service based business concepts: a typology for business to business markets. European Management Journal, 27, 442-455.

Marino, A., Bertoldi, P., \& Rezessy, S. (2010). Energy service companies market in Europe-status report 2010, JRC scientific and technical reports. Ispra: JRC.

Mourik, R., Rotmann, S., Mathijsen, T. (2014). The life of ESCo project facilitators: If only the client knew, understood, trusted, cared and engaged

Nolden, C., Sorrell, S. (2015). The role of energy service contracting in delivering energy efficiency measures for local authorities in the UK, ECEEE Summer Study on Energy Efficiency 2015, Club Belambra Les Criques, Presqu'île de Giens, Toulon/Hyères, France, 1-6 June.

Philips. (2014). Case study - National Union of Students. Philips, Guildford.

Rosenow, J., \& Eyre, N. (2015). Re-energising the UK's approach to domestic energy efficiency, ECEEE Summer Study 2015, Club Belambra Les Criques. France: Presqu'île de Giens Toulon/Hyères.
Rosenow, J., \& Sagar, R. (2015). After the Green Deal: empowering people and places. London: ResPublica.

Sayce, S., Sundberg, A., Parnell, P., \& Cowling, E. (2009). Greening leases: do tenants in the United Kingdom want green leases. Journal of Retail \& Leisure Property, 8, 273284.

Sorrell S, 2005. The contribution of energy service contracting to a low carbon economy, Tyndall Centre Technical Report No. 37. SPRU, Brighton.

Sorrell, S. (2007). The economics of energy service contracts. Energy Policy, 35, 507-521.

Sorrell, S., Schleich, J., O'Malley, E., \& Scott, S. (2004). The economics of energy efficiency: barriers to cost-effective investment. Cheltenham: Edward Elgar.

Stahel, W. (2006). The performance economy. New York: Palgrave Macmillan.

Stahel, W. R. (1997). The service economy: wealth without resource consumption? Philosophical Transactions A, Royal Society, 355, 1309-1319.

Steinberger, J. K., van Niel, J., \& Bourg, D. (2009). Profiting from negawatts: reducing absolute consumption and emissions through a performance-based energy economy. Energy Policy, 37, 361-370.

Supple, D. (2010). Financing models for energy efficiency and renewable energy in existing buildings. Washington DC, USA: Johnson Controls.

Vine, E., Nakagami, H., \& Murakoshi, C. (1999). The evolution of the US energy service company (ESCO) industry: from ESCO to super ESCO. Energy, 24, 479-492. 